\title{
Some Properties of Hop Mosaic Virus Isolated in Japan
}

\author{
Yoshiaki KANNO*, Hisashi IIDA*, Nobuyuki YosHIKAWA* \\ and Tsuyoshi TAKAHASHI*
}

\begin{abstract}
Hop mosaic virus (HMV) was isolated from a mosaic-diseased hop plant (Humulus lupulus L. cv. Sunshine). The virus systemically infected two plant species, hop (cv. Shinshuwase) and Nicotiana occidentalis and only the inoculated leaves of N. clevelandii, Chenopodium quinoa, Cucurbita maxima among 24 species of 11 families. The virus was purified from infected leaves of $N$. occidentalis, a new host suitable for propagation of HMV. Purified virus particles were $625 \mathrm{~nm}$ in length, $13 \mathrm{~nm}$ in width and composed of a single coat protein species with $\mathrm{Mr} 32,800$ daltons (Da) and a nucleic acid with $\mathrm{Mr} 2.91 \times 10^{6}$ Da. In immunosorbent electron microscopy using antisera against three carlaviruses (HMV, hop latent virus: HLV and American hop mosaic virus) the virus isolated in this study reacted with an antiserum against HMV isolated in England and also weakly with antisera against HLVS isolated in Japan and England. The survey of HMV infection in commercial hop plants indicated that HMV did not occur in hop gardens in Japan though some cultivars introduced for breeding are infected with the virus.
\end{abstract}

(Received April 4, 1994)

Key words : hop (Humulus lupulus L.), hop mosaic virus, Nicotiana occidentalis.

\section{INTRODUCTION}

Three carlaviruses are known to infect commercial hop plants (Humulus lupulus L.), i.e. hop latent virus $(\mathrm{HLV})^{2,4,14)}$, hop mosaic virus (HMV) ${ }^{1,3)}$ and American hop latent virus (AHLV) ${ }^{2,5}$. These viruses can be distinguished from each other by host reactions and serology. HMV causes hop mosaic disease in sensitive hop cultivars, in contrast to HLV and AHLV which infect hop plants latently ${ }^{1,3,10)}$.

In Japan, a filamentous virus was isolated from hop plants and identified as HLV ${ }^{8,9,16)}$. Recently, Kanno et al. ${ }^{9)}$ reported that HLV is prevalent in hop plants throughout 21 hop gardens located in 5 prefectures. Purification and characterization of HMV has not been conducted in Japan and the incidence of HMV was not been investigated extensively although Sano and Shikata ${ }^{17)}$ reported the occurrence of HMV in one limited cultivar (Brewers Gold) by serology.

In this paper, we report a new host suitable for propagation of HMV, the purification and characterization of HMV isolated in Japan, and a survey of its occurrence in commercial hop plants.

\section{MATERIALS AND METHODS}

Virus. The HMV isolated used in this study was obtained from a mosaic-diseased hop plant (cv. Sunshine: plant No. S-1) maintained in Iwate Experimental Farm, Asahi Breweries Ltd. S-1 hop leaves were ground in $0.02 \mathrm{M}$ phosphate buffer $(\mathrm{pH} 8.0$ ) containing $0.5 \% 2$-mercaptoethanol and $1 \%$ polyvinylpyrolidone (PVP) and the sap was inoculated to Nicotiana clevelandii $i^{1,3,13)}$. The inoculated leaves of $N$. clevelandii were used as inoculum sources in further experiments.

Host range. In preliminary tests, it was found that the virus could infect $N$. occidentalis

\footnotetext{
* Faculty of Agriculture, Iwate University, Ueda 3-chome, Morioka 020, Japan 岩手大学農学部
} 
systemically and inoculum for host range tests was therefore prepared by grinding infected leaves of $N$. clevelandii or $N$. occidentalis in $0.05 \mathrm{M}$ borate buffer $(\mathrm{pH} 8.0$ ) containing $1 \%$ sodium sulfate. Inoculated plants were grown in a greenhouse maintained at $20-30^{\circ} \mathrm{C}$. After $3-4$ weeks, inoculated and uninoculated upper leaves were ground in 10 volumes of PBS $(0.02 \mathrm{M}$ phosphate buffer, $0.15 \mathrm{M} \mathrm{NaCl}, \mathrm{pH} 7.4)$ containing $1 \% \mathrm{PVP}$ and $0.1 \%$ thioglycolic acid, followed by centrifugation at $10,000 \mathrm{rpm}$ for $5 \mathrm{~min}$. The supernatants were assayed by double antibody sandwich enzyme-linked immunosorbent assay (DASELISA $)^{7}$. Both Anti-HMV IgG for coating and IgG-alkaline phosphatase conjugate were used at a dilution of $1 \mu \mathrm{g} / \mathrm{ml}$.

Virus purification. The virus was purified from infected leaves of $N$. occidentalis by the procedure described by Adams and Barbara ${ }^{1)}$ except that the crude extract was clarified by a half volume of carbon tetrachloride.

Electron microscopy. Leaf sap and purified virus preparations were negatively stained with $2 \%$ uranyl acetate and examined in a Hitachi H-800 electron microscope.

Coat protein and nucleic acid. The molecular weight (Mr) of coat protein was determined by sodium dodecyl sulfate-polyacrylamide gel electrophoresis (SDS-PAGE) using the Laemmli system ${ }^{11}$. The standard proteins used were: phosphorylase $\mathrm{b}(97,400: 97.4 \mathrm{~K})$, bovine serum albumin $(66.3 \mathrm{~K})$, aldolase $(42.4 \mathrm{~K})$, carbonic anhydrase $(30.0 \mathrm{~K})$, trypsin inhibitor $(20.1 \mathrm{~K})$ and lysozyme $(14.4 \mathrm{~K})$. The protein bands were stained with $0.1 \%$ Coomassie Brilliant Blue.

Nucleic acid was extracted from purified virus preparation by the SDS-phenol method $^{6}$. The Mr of nucleic acid denatured with formaldehyde was estimated by electrophoresis in $1 \%$ agarose tubular gels containing formaldehyde ${ }^{15)}$. The gels were stained with $0.01 \%$ toluidine blue $\mathrm{O}$. Tobacco mosaic virus-RNA $\left(2.19 \times 10^{6}\right)$ and cucumber mosaic virus-RNAs $\left(1.27,1.13,0.82\right.$ and $\left.0.35 \times 10^{6}\right)$ were used as size standards.

Serology. Antiserum against HMV was prepared in a rabbit by intramuscular injections of purified virus preparations $(0.38-0.5 \mathrm{mg})$ emulsified with an equal volume of Freund's complete adjuvant on four successive weeks.

Immunosorbent electron microscopy (ISEM) was conducted as described by Milne and Luisoni ${ }^{12}$ using antisera against HLV from Japan (HLV-J) ${ }^{9}$, HLV from England (HLV-E) ${ }^{2}$, HMV from England $(\mathrm{HMV}-\mathrm{E})^{1)}$ and $\mathrm{AHLV}{ }^{2)}$. The latter three antisera were kindly supplied by Dr. A.N. Adams.

\section{RESULTS}

\section{Host range of $\mathrm{HMV}$ isolated in Japan}

Among 24 species of 11 families, the virus systemically infected two species, hop (cv. Shinshuwase) and $N$. occidentalis, without causing obvious symptoms; it also infected the inoculated leaves only of $N$. clevelandii, Chenopodium quinoa and Cucurbita maxima. No virus was recovered from the following species: Amaranthus caudatus, Gomphrena globosa (Amaranthaceae); Basella rubra (Basellaceae); Beta vulgaris, C. murale (Chenopodiaceae); Brassica campestris var pekinensis, Raphanus sativus (Cruciferae); Cucumis sativus (Cucurbitaceae); Zea mays (Gramineae); Phaseolous vulgaris, Vicia faba, Vigna sesquipedalis (Leguminosae); Sesamum indicum (Pedaliaceae); Datura stramonium, Lycopersicon esculentum, $N$. debneyi, N. glauca, N. tabacum cv. Xanthi nc (Solanaceae); Petroselinum crispum (Umbelliferae).

\section{N. occidentalis as a propagation host of HMV}

Adams and Barbara ${ }^{1)}$ purified HMV from systemically infected $N$. clevelandii. Our virus isolate (HMV-J), however, was recovered from only the inoculated leaves of $N$. clevelandii without systemic infection. To search for a suitable propagation host for purification of HMV, we compared the virus concentrations in leaves of systemically infected $N$. occidentalis and hop plants by DAS-ELISA. $A_{405}$ values of ELISA were 1.27 for infected $N$. occidentalis (4 weeks after inoculation), 0.63 for naturally infected S-1 hop, 0.41 for inoculated hop (cv. Shinshuwase, 8 weeks after inoculation) and 0.04 to 0.08 for healthy $N$. occidentalis and hop (cv. Shinshuwase) plants. We also compared the amounts of virus particles in systemically infected leaves of $N$. occidentalis and in the inoculated leaves of $N$. clevelandii 
by ISEM tests. The number of virus particles trapped by HMV antiserum from leaves of infected $N$. occidentalis was about 20 times more than that from the inoculated leaves of $N$. clevelandii. These results indicate that $N$. occidentalis is thought to be a most suitable propagation host for HMV purification.

\section{Properties of purified virus}

The UV-absorption spectrum of purified preparations showed a maximum at $259 \mathrm{~nm}$ and a

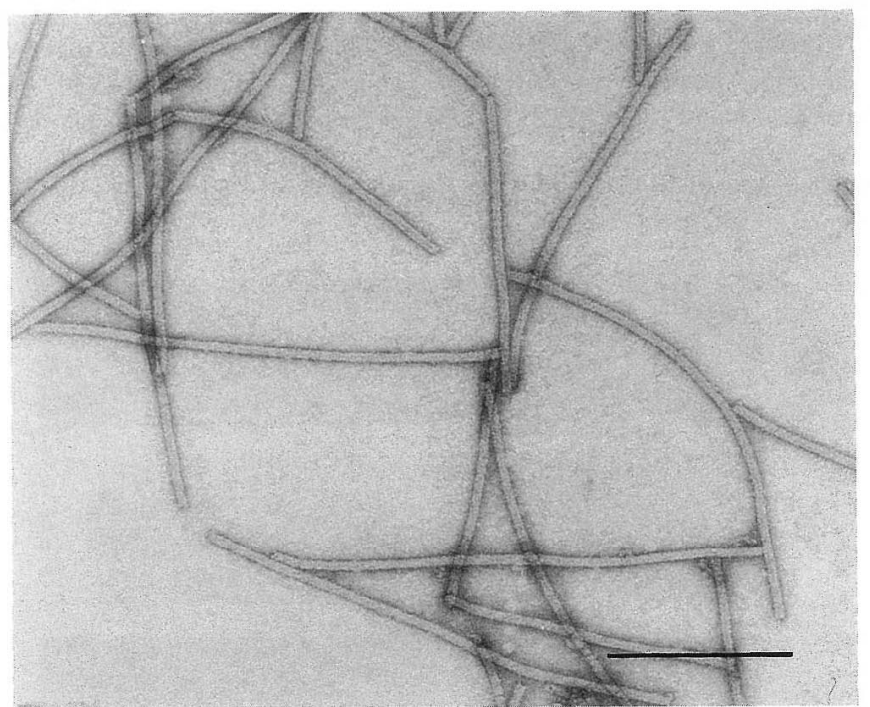

Fig. 1. Electron micrograph of purified HMV particles. Bar represents $200 \mathrm{~nm}$.

a

b

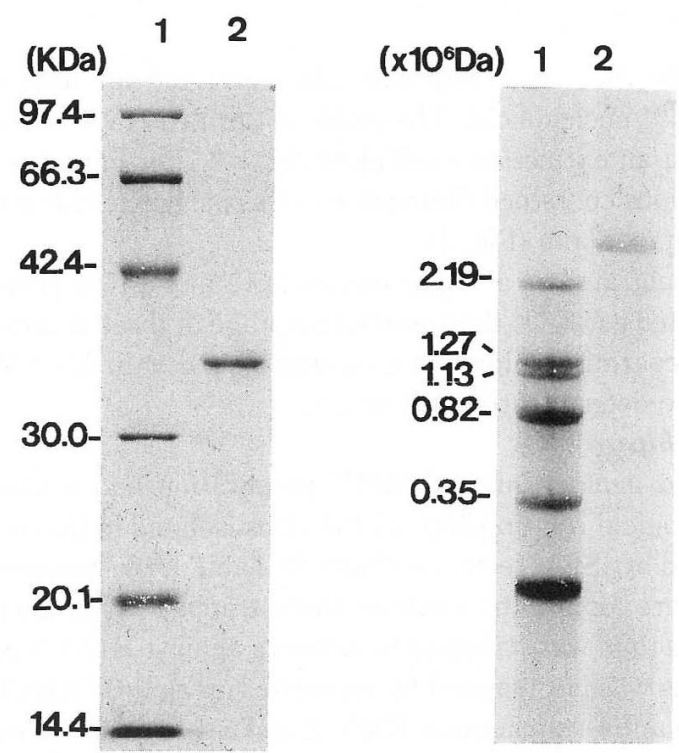

Fig. 2. Electrophoretic analyses of the coat protein and the nucleic acid of HMV. (a) Electrophoresis of viral coat protein in a SDS-10\% polyacrylamide gel. Lane 1: marker proteins, lane 2: viral coat protein. (b) Electrophoresis of viral nucleic acid denatured with formaldehyde in a $1 \%$ agarose gel. Lane 1 : marker RNAs, Lane 2: viral nucleic acid. 
Table 1. The numbers of virus particles trapped by antisera against three carlaviruses ${ }^{\mathrm{a})}$

\begin{tabular}{lc}
\hline \hline \multicolumn{1}{c}{ Antisera $^{\text {b) }}$} & ${\text { The numbers of particles } \pm \text { S.D. }{ }^{\text {c) }}}^{\text {Homologous }}$ \\
HMV-E & $48.4 \pm 9.2$ \\
HLV-J & $55.8 \pm 8.0$ \\
HLV-E & $17.6 \pm 2.4$ \\
AHLV & $14.2 \pm 4.7$ \\
PBS buffer & $0.8 \pm 0.7$ \\
\hline
\end{tabular}

a) Infected leaves of $N$. occidentalis were ground in 10 volumes of $0.5 \mathrm{M}$ borate buffer $(\mathrm{pH} 8.0)$ containing $1 \%$ sodium sulfate and then centrifuged at $10,000 \mathrm{rpm}$ for $5 \mathrm{~min}$. The supernatants was used for tests.

b) Antisera were diluted at 1/20 in PBS. HMV-E and HLV-E were against English isolates and HLV-J was against Japanese isolate.

c) The number of particles counted on $75 \times 58 \mathrm{~mm}$ at a magnification of $\times 15,000$ (Average of 5 replicants \pm standard deviation).

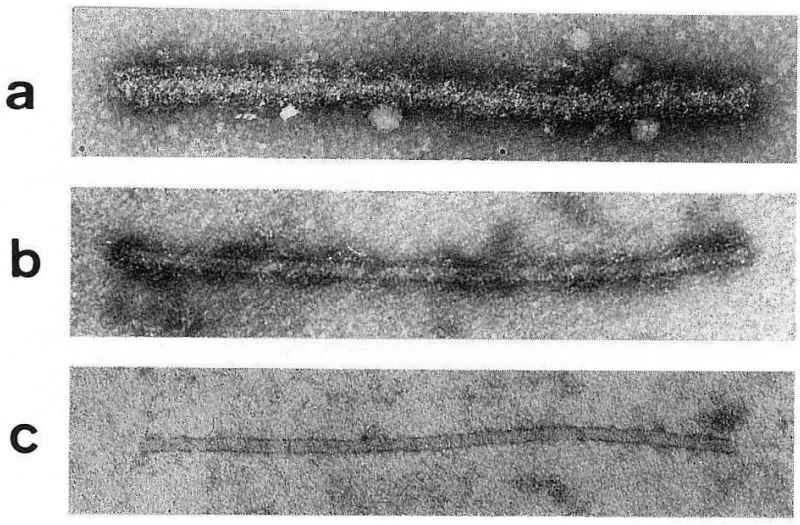

Fig. 3. Immunosorbent electron microscopy of HMV isolated in this study using antisera against (a) HMV-J, (b) HLV-J and (c) AHLV. Each antiserum was diluted at 1/20 in PBS and used for decorations.

minimum at $248 \mathrm{~nm}$, and the $A_{260} / A_{280}$ ratio was 1.18 (corrected for light scattering), indicating that virus particle contained 5-6\% nucleic acid. The yields of purified HMV were $3-8 \mathrm{mg} / \mathrm{kg}$ of fresh leaves of $N$. occidentalis, assuming an extinction coefficient $A_{260}=2.1$ for carnation latent virus ${ }^{18)}$.

Purified virus preparations contained filamentous virus particles with a modal length of $625 \mathrm{~nm}$ (208 measurements) and a width of $13 \mathrm{~nm}$ (Fig. 1).

Coat protein of HMV migrated as a single species in 10\% and 15\% polyacrylamide gels containing SDS and its $\mathrm{Mr}$ was estimated as 32,800 daltons (Da) (average of three determinations) (Fig. 2a). Nucleic acid from purified virus preparation migrated as a single band with $\mathrm{Mr} 2.91 \times 10^{6} \mathrm{Da}$ under denatured conditions (average of three determinations) (Fig. 2b).

\section{Serological relationships}

An antiserum produced against purified HMV preparation had a homologous titer of $1 / 512$ in microprecipitin tests. Serological relationships of the virus isolated in this study with carlaviruses from hop plants were investigated by ISEM tests. As shown in Table 1, the numbers of virus particles trapped by homologous antiserum are almost the same as those trapped by an antiserum against HMV from England (HMV-E) and more than were trapped by antisera against HLVs from Japan (HLV-J) and from England (HLV-E). The virus was not trapped by an antiserum against AHLV. The virus particles were also decorated heavily with antiserum against HMV-E and weakly with those against HLV-J or HLV-E (Fig. 3). From these results, the virus isolated in this study was serologically identified as HMV.

\section{Detection of HMV in hop gardens in Japan}

The occurrence of HMV in commercial hop plants was investigated in 22 hop gardens located in 7 prefectures by DAS-ELISA. HMV was not detected in any samples in 218 hop plants. However, the virus 
was found in 5 cultivars (Sunshine, Northern Breweres, Becka, Early Zugg and Spalt) out of 19 cultivars which had been introduced for breeding.

\section{DISCUSSION}

This is the first report on the biological, physical and serological properties of HMV isolated in Japan.

Three filamentous viruses (HLV, HMV and AHLV) were reported to infect hop plants ${ }^{1-5,15)}$. These viruses can be distinguished from each other by host reactions. The virus isolated in this study infected the inoculated leaves of $N$. clevelandii reported to be a host plant for HMV, but not hosts for HLV and AHLV. The virus did not infect $P$. vulgaris, C. murale (diagnostic hosts for HLV) and D. stramonium (a diagnostic host for AHLV). From these results, the virus isolated in this study is thought to be HMV.

Our HMV isolate (HMV-J) was different from the isolate in England (HMV-E) in some host reactions. In contrast with HMV-E which infected systemically both $N$. clevelandii and $N$. debneyi, HMV-J infected only the inoculated leaves of $N$. clevelandii and not $N$. debneyi. A Chinese isolate of HMV is also reported to infect $N$. clevelandii systemically ${ }^{19}$. Hop plants (cv. Shinshuwase) inoculated with purified HMV did not show any obvious symptoms. This may be because the cultivar Shinshuwase is torelant to HMV infection.

$N$. occidentalis was a satisfactory propagation host for virus purification. The virus concentration in leaves of infected $N$. occidentalis is higher than in the infected leaves of hop plants and in the inoculated leaves of $N$. clevelandii and we obtained sufficient purified virus to analyze its physical properties and to prepare antiserum.

Purified HMV was $625 \mathrm{~nm}$ in length, slightly shorter than $650 \mathrm{~nm}$ reported for HMV-E ${ }^{1)}$ and $655 \mathrm{~nm}$ for a Chinese isolate ${ }^{19}$. The molecular weight of HMV-J nucleic acid $\left(2.91 \times 10^{6} \mathrm{Da}\right)$ was essentially similar to that of HMV-E $\left(3.0 \times 10^{6} \mathrm{Da}\right)^{1)}$ and of a Chinese isolate $\left.\left(2.95 \times 10^{6} \mathrm{Da}\right)^{19}\right)$. However, coat protein of HMV-J $(32,800 \mathrm{Da})$ was slightly smaller than that of HMV-E $(34,000 \mathrm{Da})^{1)}$ and of a Chinese isolate $\left.(34,200 \mathrm{Da})^{19}\right)$. These variations may reflect differences in experimental conditions and/or virus isolate.

In ISEM tests using antisera against three carlaviruses from hop plants, HMV-J was trapped and decorated heavily with an antiserum against HMV-E. HMV-J also shared a distant serological relationship with HLV, in agreement with the results of Adams and Barbara ${ }^{2}$.

The survey of HMV infection in commercial hop plants indicated that HMV did not occur in hop gardens in Japan although some cultivars introduced for breeding are infected with the virus. The result contrasts with the high incidence of HLV ( $75.2 \%$ of hop plants tested $)^{9}$.

We gratefully acknowledge Dr. A.N. Adams, Horticulture Research International East Malling, U.K. for providing antisera and for critical reading of the manuscript and Dr. T. Sano, Faculty of Agriculture, Hirosaki University for useful discussion. We are also indebted to several brewery companies and to several hop agricultural co-operative associations for supplying hop leaf samples.

\section{Literature cited}

1. Adams, A.N. and Barbara, D.J. (1980). Host range, purification and some properties of hop mosaic virus. Ann. appl. Biol. $96: 201-208$.

2. Adams, A.N. and Barbara, D.J. (1982). Host range, purification and some properties of two carlaviruses from hop (Humulus lupulus): hop latent and American hop latent. Ann. appl. Biol. 101 : 483-494.

3. Barbara, D.J. and Adams, A.N. (1981). Hop mosaic virus. CMI/AAB Descriptions of Plant Viruses No. 241.

4. Barbara, D.J. and Adams, A.N. (1983). Hop latent virus. CMI/AAB Descriptions of Plant Viruses No. 261.

5. Barbara, D.J. and Adams, A.N. (1983). American Hop latent virus. CMI/AAB Descriptions of Plant Viruses No. 262.

6. Bem, F. and Murant, A.F. (1979). Comparison of particle properties of heraclem latent and apple chlorotic leaf spot viruses. J. Gen. Virol. $44: 817-826$.

7. Clark, M.F. and Adams, A.N. (1977). Characteristics of the microplate method of enzyme-linked immunosorbent assay for the detection of plant viruses. J. Gen. Virol. 34 : 475-483. 
8. Inoue, M., Shikata, E. and Murayama, T.(1973). Properties and pathogenicity of the rod-shaped virus isolated from hop plant. Ann. Phytopath. Soc. Japan 39 : 229 (Abstr. in Japanese).

9. Kanno, Y., Yoshikawa, N. and Takahashi, T. (1993). Some properties of hop latent and apple mosaic viruses isolated from hop plants and their distributions in Japan. Ann. Phytopath. Soc. Japan 59: 651-658.

10. Keyworth, W.G. (1947). Mosaic disease of the hop-a study of tolerant and sensitive varieties. Rept. East Malling Res. Stn. for 1946. pp. 142-148.

11. Laemmli, U.K. (1970). Cleavage of structural proteins during the assembly of the head bacteriophage T4. Nature 227: 680-685.

12. Milne, R.G. and Luisoni, E. (1977). Rapid immune electron microscopy of virus preparation. In Methods in Virology, Vol. VI (Maramorosch, K. and Koprowski, H. eds.). Academic Press, New York. pp. 265-281.

13. Probasco, E.G. and Skotland, C.B. (1976). A technique for the differential isolation of hop mosaic virus and hop latent virus. Can. J. Microbiol. 22 : 1160-1162.

14. Probasco, E.G. and Skotland, C.B. (1978). Host range, general properties, purification, and electron microscopy of hop latent virus. Phytopathology $68: 277-281$.

15. Sambrook, J., Fritsch, F. and Maniatis, T. (1989). Molecular Cloning: A Laboratory Manual. 2nd ed. Cold Spring Harbor Laboratory Press, New York.

16. Sano, T., Sasaki, M. and Shikata, E. (1981). Prunus necrotic ringspot virus and hop latent virus isolated from hop plants in Japan. Ann. Phytopath. Soc. Japan. $47: 411$ (Abstr. in Japanese).

17. Sano, T. and Shikata, E. (1991). Hop virus diseases in Japan. In Proc. Intl. Workshop on Hop Virus Diseases (Eppler, A. ed.). Eugen Ulmer, Stuttgart. pp. 3-11.

18. Wetter, C. (1971). Carnation latent virus. CMI/AAB Description of Plant viruses No. 61.

19. Yu, J. and Liu, Y. (1987). The occurrence of three viruses in hop (Humulus lupulus) in China. Plant Pathol. $36: 38-44$.

\section{和 文 摘 要}

菅野善明・飯田 久・吉川信幸・高橋 壯：わが国のホップから分離されたホップモザイクウイルスの 2,3 の性質

モザイク症状を呈したホップ (Humulus lupulus L. 品種：Sunshine）からホップモザイクウイルス (hop mosaic virus：HMV) を分離した。本ウイルスの宿主範囲を 11 科 24 種の植物について調査した結果, ホップ (品種：信州早 生）扔よびNicotiana occidentalis に全身感染し，N. clevelandii, Chenopodium quinoa およびカボチャでは接種葉の みに感染した。HMV の堌殖宿主として N. occidentalis が適しており, 本植物の感染葉から HMV を精製した。精製 ウイルス粒子は長さ $625 \mathrm{~nm}$, 幅 $13 \mathrm{~nm}$ のひも状粒子で, 分子量 32,800 ダルトンの 1 種類の外被夕ンパク質と分子量 $2.91 \times 10^{6}$ ダルトンの 1 種類の核酸からなっていた。本ウイルスとこれまでにホップから分離された 3 種 carlavirus （HMV，ホップ潜在ウイルス；HLV, American hop latent virus）との血清関連を免疫電顕法により調査した結果， 本ウイルスは英国で分離された HMV に対する抗血清と強く反応し, 日本拉よび英国で分離された HLV に対する抗 血清と弱く反応した。わが国のホップ栽培圈場における HMV の発生を調査したところ, 栽培ホップにおける発生は認 められなかったが，育種材料として用いられている数種導入品種から HMV が検出された。 